\title{
YIELD AND NUTRIENT UPTAKE OF SOME FABA BEAN VARIETIES GROWN IN NEWLY CULTIVATED SOIL AS AFFECTED BY FOLIAR APPLICATION OF HUMIC ACID Afifi, M. H. M. *; Manal F. Mohamed ${ }^{*}$ and S. H. A. Shaaban ** * Dept. of Field Crop Research National Res. Centre, Dokki, Cairo, Egypt ${ }^{* \star}$ Dept. of Fertilization Technology National Res. Centre, Dokki, Cairo, Egypt
}

\begin{abstract}
Two field experiments were conducted in sandy soil under salinity conditions in El-Emam El-Ghazaly Village, South El-Tahrir Province, El-Behaira Governorate, Egypt, during the two winter successive seasons 2006/2007 and 2007/2008 using three faba bean (Vicia faba L.) varieties, namely: Giza-461, Giza-3, Giza-429, to study the effect of foliar spray of commercially produced humic acid $2.9 \%$, containing N,P,K $(10,10,10 \%)$ used during the growing season at concentrations of $0,5,10,20 \mathrm{~cm} / \mathrm{l}$ on yield and yield components as well as nutrient uptake in faba bean seeds. There were significant differences between treatments and control for seed yield, biological yield and harvest index. The reaction between the treatments and the varieties showed that foliar application of humic acid for Giza-461 at concentration of $20 \mathrm{~cm} / \mathrm{l}$ enhanced the number and weight of pods and straw as well as seed, biological yield. All treatments of humic increased the nutrient uptake more than control. The highest $\mathrm{N}$ uptake was attained with $20 \mathrm{~cm} / \mathrm{l}$ and the highest $\mathrm{Fe}$ and $\mathrm{Mn}$ uptake was with $5 \mathrm{~cm} / \mathrm{l}$. The highest uptake of nutrients as affected by humic foliar application was obtained from $20 \mathrm{~cm} / \mathrm{L}$ with Giza-461, from $5 \mathrm{~cm} / \mathrm{L}$ with Giza-3 and $10 \mathrm{~cm} / \mathrm{L}$ with Giza-429. It seems that foliar application of humic acid under such conditions is more effective in improving seed nutrient uptake and yield of faba bean varieties under study.
\end{abstract}

Keywords: Faba bean (Vicia faba L.), humic acid, foliar application, nutrients uptake, yield.

\section{INTRODUCTION}

Faba bean (Vicia faba L.) is one of the most important food crops in Egypt. It is considered one of the main sources of plant proteins for human nutrition in Egypt. It covers a considerable part of protein although its production is insufficient to meet the total demand in the country. High yield production of faba bean is urgently needed to meet the increasing population and growing demand for protein food in Egypt. According to Central Agency for Public Mobilization and Statistics (1996), its yields are still below the potential of its modern cultivars. Continuous efforts are carried out to improve its productivity, especially in newly reclaimed areas which have low nutrient contents, high $\mathrm{pH}$, low organic matter content and high salinity. Legumes are among the crops whose yields are limited under such conditions (Sillanpãã, 1982, El-Fouly et al., 1984, Hafiz \& El-Kholy, 2001).

Humic substances are well known as complexing agents for transition metal cations, thereby facilitating enhanced nutrients uptake (Chen et al., 2001).

There are a few studies on using humic acid as foliar application, although previous studies in the literature have shown that humic acid as foliar sprays enhanced growth, nutrient uptake and yield in some crops 
(David 1991, El-Desuki 2004, Delfine et al., 2005, Mani Sangeetha et al., 2006, Ramasamy Natesan et al., 2006).

The soil of the South El-Tahrir sector is sandy in textures which have low nutrient contents. Further information is needed on humic acid effect on yield of faba bean. Thus, the objective of this work was to study if humic acid when used as a foliar application can improve yield and seed nutrient uptake of some faba bean varieties grown in newly reclaimed areas.

\section{MATERIALS AND METHODS}

Two field experiments were carried out in El-Emam El-Ghazaly Village, South El-Tahrir Province, El-Behaira Governorate, Egypt, during two winter consecutive seasons (2006/2007 and 2007/2008) The trials were performed on three faba bean (Vicia faba L.) varieties: Giza-461, Giza-3 and Giza-429, humic acid $2.9 \%$ containing N,P,K $(10,10,10 \%)$ was used in this work. Soil surface samples $(0-30 \mathrm{~cm}$ depth) were taken before sowing from the experimental site. Soil was air-dried and sieved through $2 \mathrm{~mm}$ pores sieve for determination of, Physic-chemical characteristics. According to the tentative values of soil characteristics and available nutrient concentrations, data presented in Table (1) reveal that the experimental soil is sandy in texture, tented to alkalinity in reaction. It had low content of calcium carbonate, very low in organic matter, E.C and Na were high. Low in phosphorus, potassium and magnesium as well as micronutrients, Seeds of faba bean varieties were inoculated prior to sowing with the specific strain of Rhizobium Leguminosarum and were sown at the rate of $75 \mathrm{Kg} / \mathrm{fed}$, on $15^{\text {th }}$ November during the two growing seasons. Phosphorus was applied to soil before planting at the level of $31 \mathrm{Kg} \mathrm{P}_{2} \mathrm{O}_{5} / \mathrm{fed}$ as calcium super phosphate $(15.5 \%$ $\mathrm{P}_{2} \mathrm{O}_{5}$ ). Nitrogen was applied at the level of $30 \mathrm{Kg} \mathrm{N} / \mathrm{fed}$ as ammonium sulphate $20.6 \% \mathrm{~N}$ at the beginning of tillering, while potassium was added as potassium sulphate $\left(48 \% \mathrm{~K}_{2} \mathrm{O}\right)$ at a rate of $24 \mathrm{Kg} \mathrm{K}$ O/fed during pod filling. Foliar application with humic acid $2.9 \%$ was done at 40 days after sowing with a rate of 200 litre of solution/fed. The plants were irrigated by sprinkler irrigation from water having $\mathrm{pH} 7.15$ and $\mathrm{EC} 1.37 \mathrm{dS} / \mathrm{m}$.

Table 1: Soil physico- chemical characteristics of the experimental farm.

\begin{tabular}{|ll|lc|}
\hline \multicolumn{2}{|c|}{ Character } & \multicolumn{1}{c|}{ Available nutrients } \\
\hline Sand \% & 86.00 & $\mathrm{P}$ & $(\mathrm{mg} / 100 \mathrm{~g})$ \\
\hline Silt \% & 11.00 & $\mathrm{~K}$ & $00.85 \mathrm{~L}$ \\
\hline Clay \% & 03.00 & $\mathrm{Mg}$ & $05.01 \mathrm{VL}$ \\
\hline Soil Texture & Sandy & $\mathrm{Ca}$ & $15.00 \mathrm{~L}$ \\
\hline $\mathrm{pH}$ & $07.47 \mathrm{H}$ & $\mathrm{Na}$ & $140.00 \mathrm{~L}$ \\
\hline $\mathrm{EC} \mathrm{dS} / \mathrm{m}$ & $01.87 \mathrm{H}$ & & $60.00 \mathrm{H}$ \\
\hline $\mathrm{CaCO} \%$ & $01.98 \mathrm{~L}$ & $\mathrm{Fe}$ & $07.40 \mathrm{~L}$ \\
\hline $\mathrm{O} . \mathrm{M} \%$ & $00.44 \mathrm{VL}$ & $\mathrm{Mn}$ & $06.50 \mathrm{~L}$ \\
\hline & & $\mathrm{Zn}$ & $01.28 \mathrm{~L}$ \\
\hline & $\mathrm{Cu}$ & $00.80 \mathrm{~L}$ \\
\hline & & &
\end{tabular}


The different soil features were determined as follows:

Texture: Hydrometer method (Bouyoucos, 1954).

$\mathrm{pH}$ and EC: in 1:2.5 soil/water suspension (Chapman and Pratt, 1978).

$\mathrm{CaCO}_{3}$ : Collin's calcimeter (Alison and Moodle, 1965).

O.M: Black method (Isaac and Johnson, 1984).

$\mathrm{P}$ : NaHCO3 extraction at $\mathrm{pH} 8.5$ (Olsen et al., 1954).

$\mathrm{K}, \mathrm{Ca}$ and $\mathrm{Mg}$ : NH4-OAc extraction at $\mathrm{pH} 7$ (Jackson, 1973).

$\mathrm{Fe}, \mathrm{Mn}, \mathrm{Zn}$ and $\mathrm{Cu}$ : DTPA extraction at pH 7.3 (Lindsay and Norvell, 1978).

Four treatments of humic acid were tested as follows:

1. Control (without foliar application of humic acid)

2. Humic acid at concentration of $05 \mathrm{~cm} / \mathrm{I}$ of water

3. Humic acid at concentration of $10 \mathrm{~cm} / \mathrm{I}$. of water

4. Humic acid at concentration of $20 \mathrm{~cm} / \mathrm{I}$. of water

Treatments were arranged in a split plot design with three replicates.

Varieties occupied the main plots and humic treatments were allocated at random in the sub plots, each plot was $10.5 \mathrm{~m}^{2}$ in area (1/400 fed).

Ten-guarded plants were taken randomly from each plot for all treatments to determine plant height, number of branches and pods, weight of pods and seeds. At full maturity all plants from each plot of the different treatments and varieties were collected to estimate seed and straw yield.

Total $\mathrm{N}$ was determined in the dry seeds using Kjeldahl method; total $P$ was photo metrically determined using molybdate-vanadate method, while, total $\mathrm{K}, \mathrm{Ca}$ and $\mathrm{Na}$ were determined using flame photometer. Micronutrients and magnesium was measured using atomic absorption spectrophotometer, according to Chapman and Pratt (1978)

The data were statistically analyzed as split plot design according to Snedecor and Cochran (1980). Comparisons among means of treatments were tested for significance against L.S.D values at $5 \%$ level of probability proposed by Waller and Duncan (1969).

\section{RESULTS AND DISCUSSION}

\section{Yield Components}

Data presented in Table 2 exhibited that Giza 429 was the highest in plant height, number and weight of pods/plant and straw yield, while Giza 3 was the lowest in the most of characteristics. As for effect of foliar sprays of humic acid on yield and its components, Table 3 showed that there were significant differences between treatments and control for seed yield, biological yield and harvest index whereas no significant differences found between treatments and control for plant height, number of branches, number and weight of pods/plant and straw yield. However, data presented in Table 4 show that foliar application of humic acid for Giza-461 at concentration of 20 $\mathrm{cm} / \mathrm{l}$ enhanced the number, weight of pods and straw as well as seed and biological yield. 
Table 2: Effect of varieties on growth characters, yield and yield components of faba bean. (Combined analysis of two seasons)

\begin{tabular}{|c|c|c|c|c|c|c|c|c|c|c|c|}
\hline Character & 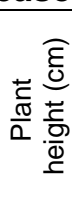 & 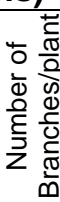 & 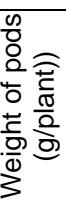 & 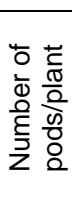 & 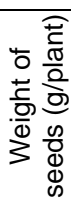 & 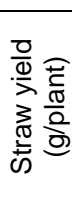 & $\begin{array}{l}x \\
\frac{x}{0} \\
. \subseteq \\
0 \\
\Phi \\
0 \\
\infty\end{array}$ & 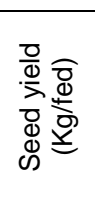 & 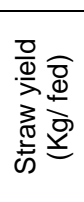 & 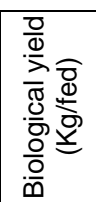 & 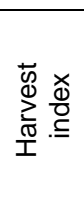 \\
\hline aiza-461 & 55.7 & 3.8 & 45.7 & 14.5 & 31.8 & 11.6 & 84.4 & 1272.8 & 469.7 & 1742.5 & 0.728 \\
\hline aiza-3 & 49.3 & 2.9 & 35.0 & 9.9 & 28.1 & 9.7 & 81.4 & 1121.9 & 387.7 & 1509.6 & 0.741 \\
\hline Giza-429 & 62.1 & 3.6 & 51.1 & 17.9 & 30.3 & 13.8 & 85.2 & 1212.6 & 550.1 & \begin{tabular}{|l|}
1762.7 \\
\end{tabular} & 0.688 \\
\hline LSD 5\% & 1.94 & 0.27 & 2.14 & 0.59 & 1.61 & 0.60 & 3.50 & 64.32 & 24.15 & 97.24 & 0.032 \\
\hline
\end{tabular}

${ }^{\star}$ Feddan $=0.42$ ha

Table 3: Effect of foliar sprays of humic acid on growth characters, yield and yield components of faba bean (Combined analysis of two seasons)

\begin{tabular}{|c|c|c|c|c|c|c|c|c|c|c|c|}
\hline Treatment & 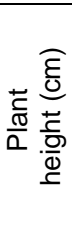 & 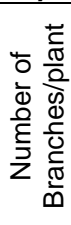 & 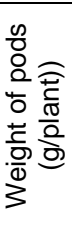 & 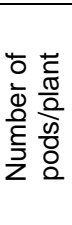 & 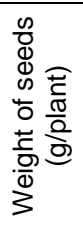 & 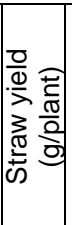 & 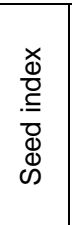 & 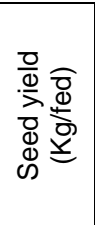 & 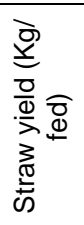 & 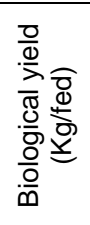 & 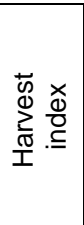 \\
\hline Control & 56.2 & 3.8 & 45.2 & 13.8 & 24.0 & 12.0 & 84.9 & 958.1 & 480.4 & 1438.5 & 0.672 \\
\hline $5 \mathrm{~cm}$ humic acid/l & 53.6 & 3.4 & 44.7 & 12.4 & 32.3 & 11.6 & 84.9 & 1292.0 & 465.0 & 1757.1 & 0.734 \\
\hline $10 \mathrm{~cm}$ humic acid/l & 57.2 & 3.4 & 42.0 & 15.3 & 31.9 & $\mid 11.5$ & 84.2 & 1274.2 & 465.9 & 1740.1 & 0.739 \\
\hline $20 \mathrm{~cm}$ humic acid/l & 55.7 & 3.2 & 43.7 & 14.8 & 32.1 & 11.6 & 80.6 & 1285.2 & 465.5 & 1750.7 & 0.730 \\
\hline SD 5\% & 1.95 & 0.51 & 3.17 & 1.54 & 2.11 & 0.71 & 7.35 & 84.15 & 28.65 & 112.80 & 0.032 \\
\hline
\end{tabular}

Table 4: Effect of interaction treatments on vegetative growth and yield of faba bean (Combined analysis of two seasons)

\begin{tabular}{|c|c|c|c|c|c|c|c|c|c|c|c|c|}
\hline$\frac{\vec{d}}{\frac{\pi}{\frac{\pi}{\pi}}}$ & 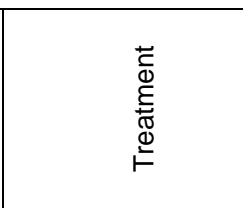 & 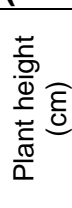 & 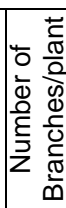 & 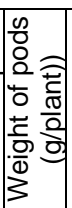 & 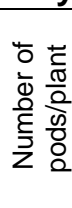 & 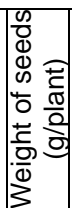 & 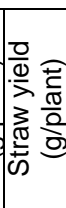 & 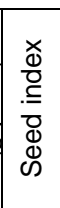 & 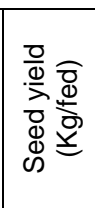 & 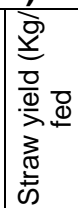 & 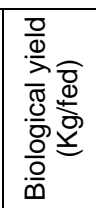 & 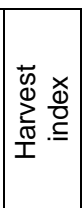 \\
\hline \multirow{4}{*}{$\begin{array}{c}\text { Giza- } \\
461\end{array}$} & Control & 57.0 & 4.2 & 48.5 & 15.2 & 26.7 & 13.2 & 80.6 & 1066.8 & 527.6 & 1594.4 & 0.669 \\
\hline & $5 \mathrm{~cm}$ humic $\mathrm{acid} / \mathrm{l}$ & 49.0 & 3.5 & 36.0 & 10.8 & 28.1 & 10.1 & 87.3 & 1124.8 & 404.8 & 1529.6 & 0.735 \\
\hline & $10 \mathrm{~cm}$ humic acid/l & 56.7 & 3.7 & 40.5 & 13.6 & 30.1 & 9.33 & 83.8 & 1204.4 & 393.2 & 1597.6 & 0.754 \\
\hline & $20 \mathrm{~cm}$ humic acid/l & 60.0 & 3.7 & 57.6 & 18.2 & 42.4 & 13.8 & 86.1 & 1695.2 & 553.2 & 2248.4 & 0.754 \\
\hline \multirow{4}{*}{$\begin{array}{c}\text { Giza- } \\
3\end{array}$} & Control & 45.0 & 3.3 & 27.0 & 7.7 & 20.6 & 7.8 & 83.3 & 823.6 & 311.2 & 1134.8 & 0.726 \\
\hline & $5 \mathrm{~cm}$ humic $\mathrm{acid} / \mathrm{l}$ & 51.8 & 3.3 & 44.1 & 8.3 & 38.6 & 12.8 & 84.4 & 1544.4 & 512.0 & 2056.4 & 0.751 \\
\hline & $10 \mathrm{~cm}$ humic acid/l & 50.0 & 2.5 & 36.8 & 14.7 & 29.1 & 8.2 & 81.4 & 1164.2 & 326.0 & 1490.2 & 0.781 \\
\hline & $20 \mathrm{~cm}$ humic acid/l & 50.5 & 2.5 & 31.9 & 9.0 & 23.9 & 10.0 & 76.3 & 955.2 & 401.6 & 1356.8 & 0.704 \\
\hline \multirow{5}{*}{$\begin{array}{c}\text { Giza- } \\
429\end{array}$} & Control & 66.7 & 3.8 & 60.0 & 18.5 & 24.6 & 15.1 & 90.8 & 984.0 & 602.4 & 1586.4 & 0.620 \\
\hline & $5 \mathrm{~cm}$ humic $\mathrm{acid} / \mathrm{l}$ & 60.0 & 3.3 & 53.9 & 18.0 & 30.2 & 12.0 & 82.9 & 1207.2 & 478.0 & 1685.2 & 0.716 \\
\hline & $10 \mathrm{~cm}$ humic acid/l & 65.0 & 4.0 & 48.8 & 17.7 & 36.4 & 17.0 & 87.5 & 1454.0 & 678.4 & 2132.4 & 0.68 \\
\hline & nic acid/l & 56.7 & 3.3 & 41.7 & 17.3 & 30.1 & 11.0 & 79.5 & 1205.2 & 441.6 & 1646.8 & 0.73 \\
\hline & LSD 5\% & 3.89 & 0.54 & 4.28 & 1.19 & 3.22 & 1.20 & 7.0 & \begin{tabular}{|l|l|}
128.6 \\
\end{tabular} & 48.29 & 194.5 & 0.064 \\
\hline
\end{tabular}


Concerning the positive effect of humic on yield, Castro et al. (1988) found that humic acid applied as foliar sprays at 1 quart/acre greatly increased the yield of extra large fruits of tomato, Chen and Aviad (1990) suggested $0.45 \mathrm{lb} /$ acre as the minimum amount of foliar applied humic acid to elicit an increase in crop productivity. Also, Hu and Wang (2001) mentioned that KOMIX, humic acid used as soil treatment or as spray at the seedling stage significantly increased the yield, seeds per plant, pods per plant, seed weight per plant, 100 -seed weight and chlorophyll content of springing soybean plants. Also, promoted the growth and developments of spring soybean plants.

The increase in seed yield may be due to hormonal effect of humic acids that improve the nutrient status of plants. Chen and Aviad, (1990) pointed out that humic are important for plant growth hormones. Dorneanu et al. 2008, reported that humic acids enhance the penetration of nutritive ions in leaves, stimulate the formation of some physiologically active metabolite compounds, enlarge the capacity of plants for root absorption of elements from soil.

\section{Seed nutrient uptake}

Results in Table 5 showed that foliar application of humic acid resulted in the highest uptake of $\mathrm{Mg}$ and $\mathrm{Mn}$, for Giza-461. The lowest uptake of $\mathrm{N}$ and $\mathrm{Ca}$ was observed for Giza-429. On opposite, the uptake of $\mathrm{P}$ was the highest in the same variety. Regarding the uptake of $\mathrm{Zn}$ and $\mathrm{Cu}$, Giza-3 was the lowest whereas was the highest for Fe. On the other hand, there is no difference of significant found between all varieties with respect to seed $\mathrm{K}$ uptake. The data in Table 6 showed that all treatments of humic increased the nutrients uptake over control. The highest $\mathrm{N}$ uptake was attained with $20 \mathrm{~cm} / \mathrm{l}$ and the highest Fe and $\mathrm{Mn}$ uptake was recorded with $5 \mathrm{~cm} / \mathrm{l}$.

The highest uptake of nutrients as affected by humic foliar application and faba bean varieties was obtained from $20 \mathrm{~cm} / \mathrm{L}$ with Giza- 461 , from $5 \mathrm{~cm} / \mathrm{L}$ with Giza-3 and $10 \mathrm{~cm} / \mathrm{L}$ with Giza-429, (Table7).

In this respect, Chiu (1990) mentioned that iron is required for several key enzymes in legumes, and for this reason, all legumes have a high iron requirement. Tang et al. (1992) mentioned that iron deficiency severely depresses nodule mass, nodule hemoglobin content and crop yield.

It is known that zinc is active in many enzymatic reactions and a high soil pH means that zinc is less soluble. Crops under these soil conditions may suffer from zinc deficiency. In this respect, El-Fouly (1982), Abd El-Hadi et al. (1986) found that highest yield increments were associated with foliar spraying of micronutrient elements especially $\mathrm{Zn}$ chelate. They found that faba bean is pulse crop most sensitive to zinc deficiency, especially if soils have a pH higher than 7.0. Concerning Mg, Hafiz and El-Kholy (2001) found that foliar application of $\mathrm{Mg}$ on the lupine, significantly increased root length, plant height, number of branches, dry weight, chlorophyll content, number of pods, pod and seed yields. Also, Saad and El-kholy (2001) found that most of the growth parameters and yield components of faba bean significantly increased with the foliar application of magnesium.

As can be observed from the data in Table 1, there is a high value of $\mathrm{EC}$ and $\mathrm{Na}$. It is known that under saline conditions, the nutrients uptake 
decreased and induced nutrient deficiencies. These deficiencies reduce plant growth and crop yield. Reduce deficit by easily readily absorbed forms of humic by plant foliage could led to improving nutrient status and improved yield and yield components. The improvment in nutrient contents by spraying humic acid previously mentioned by some authors such as Wittwer and Bukovac (1969) who found that foliar application improved root growth and led to greater absorbing surface. Also, Guvenc et al. (1999) found that nutrient contents of leaves of lettuce treated with foliar HA and Trisert-CB were significantly higher than those of controls.

Table 5: Effect of varieties on nutrient uptake of faba bean seeds (Combined analysis of two seasons)

\begin{tabular}{|l|c|c|c|c|c|c|c|c|c|c|}
\hline $\begin{array}{c}\text { Nutrient } \\
\text { Variety }\end{array}$ & $\mathbf{N}$ & $\mathbf{P}$ & \multicolumn{1}{|c|}{$\begin{array}{c}\mathbf{K} \\
\text { kg/feddan }\end{array}$} & $\mathbf{C a}$ & $\mathbf{M g}$ & $\mathbf{F e}$ & \multicolumn{1}{|c|}{$\begin{array}{c}\text { Zn } \\
\text { g/feddan }\end{array}$} & $\mathbf{C u}$ \\
\hline Giza-461 & 32.1 & 0.64 & 14.5 & 1.65 & 1.55 & 40.4 & 9.9 & 38.9 & 8.1 \\
\hline Giza-3 & 32.7 & 0.57 & 14.8 & 1.63 & 1.17 & 50.6 & 8.8 & 36.2 & 6.8 \\
\hline Giza-429 & 27.0 & 0.71 & 15.4 & 1.51 & 1.20 & 41.7 & 8.9 & 38.4 & 9.0 \\
\hline LSD 5\% & 1.93 & 0.08 & 0.91 & 0.11 & 0.04 & 2.75 & 0.75 & 2.09 & 0.61 \\
\hline
\end{tabular}

Table 6: Effects of foliar sprays of humic acid on nutrient uptake of faba bean seed (Combined analysi of two seasons)

\begin{tabular}{|c|c|c|c|c|c|c|c|c|c|}
\hline Treatment & $\mathbf{N}$ & $\mathbf{P}$ & fedd & $\mathrm{Ca}$ & $\mathbf{M g}$ & $\mathrm{Fe}$ & $\begin{array}{l}\mathrm{Mn} \\
\mathrm{g} / \mathrm{fe}\end{array}$ & $\mathrm{Zn}$ & $\mathrm{Cu}$ \\
\hline Control & 23.2 & 0.48 & 11.5 & 1.24 & 0.95 & 27.1 & 7.0 & 25.8 & 5.2 \\
\hline $5 \mathrm{~cm}$ humic acid/l & 32.5 & 0.69 & 16.3 & 1.79 & 1.47 & 54.6 & 11.0 & 41.2 & 9.7 \\
\hline $10 \mathrm{~cm}$ humic acid/l & 30.6 & 0.70 & 16.1 & 1.60 & 1.37 & 48.2 & 9.9 & 40.4 & 7.9 \\
\hline $20 \mathrm{~cm}$ humic acid/l & 36.1 & 0.68 & 15.7 & 1.75 & 1.42 & 47.1 & 8.9 & 43.9 & 9.1 \\
\hline LSD 5\% & 1.45 & 0.06 & 0.97 & 0.22 & 0.06 & 3.14 & 1.22 & 2.99 & 0.74 \\
\hline
\end{tabular}

* Feddan = 0.42 ha

Table 7: Effect of interaction of treatments and varieties on nutrient uptake of faba bean seeds

\begin{tabular}{|c|c|c|c|c|c|c|c|c|c|c|}
\hline Variety & Treatment & \multicolumn{5}{|c|}{ Kg/feddan* } & \multicolumn{4}{|c|}{ g/feddan } \\
\hline \multirow{4}{*}{ Giza-461 } & Control & 23.3 & 0.53 & 10.5 & 1.43 & 1.10 & 24.3 & 6.8 & 25.9 & 4.7 \\
\hline & $5 \mathrm{~cm}$ humic acid/l & 27.9 & 0.61 & 12.9 & 1.42 & 1.60 & 41.1 & 9.8 & 33.7 & 8.8 \\
\hline & $10 \mathrm{~cm}$ humic acid/l & 31.3 & 0.58 & 14.7 & 1.40 & 1.51 & 41.6 & 9.4 & 37.1 & 9.0 \\
\hline & $20 \mathrm{~cm}$ humic acid// & 45.8 & 0.83 & 20.0 & 2.34 & 1.97 & 54.6 & 13.7 & 59.0 & 10.0 \\
\hline \multirow{4}{*}{ Giza-3 } & Control & 21.9 & 0.32 & 11.2 & 1.02 & 0.80 & 35.4 & 6.6 & 25.5 & 4.5 \\
\hline & $5 \mathrm{~cm}$ humic acid// & 48.7 & 0.85 & 20.7 & 2.38 & 1.58 & 72.6 & 12.4 & 52.5 & 10.7 \\
\hline & $10 \mathrm{~cm}$ humic acid/l & 28.5 & 0.64 & 15.4 & 1.79 & 1.25 & 47.7 & 9.3 & 36.1 & 4.5 \\
\hline & $20 \mathrm{~cm}$ humic acid/l & 31.7 & 0.46 & 11.9 & 1.32 & 1.03 & 46.8 & 6.7 & 30.6 & 7.6 \\
\hline \multirow{5}{*}{ Giza-429 } & Control & 24.3 & 0.59 & 12.8 & 1.28 & 0.95 & 21.7 & 7.7 & 25.9 & 6.4 \\
\hline & $5 \mathrm{~cm}$ humic acid/l & 21.0 & 0.62 & 15.2 & 1.56 & 1.23 & 50.1 & 10.7 & 37.4 & 9.7 \\
\hline & $10 \mathrm{~cm}$ humic acid/l & 32.0 & 0.87 & 18.3 & 1.60 & 1.34 & 55.3 & 11.1 & 48.0 & 10.2 \\
\hline & $20 \mathrm{~cm}$ humic acid/l & 30.7 & 0.76 & 15.1 & 1.58 & 1.27 & 39.8 & 6.2 & 42.2 & 9.6 \\
\hline & LSD $5 \%$ & 3.84 & 0.11 & 1.83 & 0.22 & 0.08 & 5.49 & 1.50 & 4.17 & 1.20 \\
\hline
\end{tabular}

From the above mentioned results, it may be concluded that humic acid as foliar application have positive effect on plant nutrients and can 
reduce nutrient deficiencies, under saline conditions particularly at a rate of $20 \mathrm{~cm} / \mathrm{l}$. Also, cultivars differed in response to foliar application of humic acid, and variety Giza-461 showed the most beneficial response in this respect.

\section{Conclusion}

From the present study, it can be concluded that foliar application with humic acid improved nutrient status and balanced nutrient supply, which, promoted yield and yield components of faba bean plants grown under unfavorable soil conditions. Foliar application of humic acid for Giza-461 at concentration of $20 \mathrm{~cm} / \mathrm{l}$ was the best.

\section{Acknowledgment}

This work was conducted as a part of the Egypt-German Project "Micronutrients and Other Plant Nutrition Problems" executed by the National Research Centre (NRC), Fertilization Technology Department (Coordinator, Prof. Dr. M.M. El-Fouly) and the Institute for Plant Nutrition, Technical University, Munich (Prof. Dr. A. Amberger). The Egyptian Academy of Scientific Research and Technology (ASRT) and the German Federal Ministry of Technical Cooperation (BMZ) through the German Agency for Technical Cooperation (GTZ), supported the project

\section{REFERENCES}

Abdel-Hadi, A. H; Asy, K.S; Doering, H.W.; Kadr, M.S; Mohamed, Y.H. and Moustafa, A. A. (1986) Effect of foliar fertilization on different crops under Egyptian conditions. Proc. 1 st Intern. Symp. Foliar Fertilization, March 14-16, 1985., pp. 126-141.

Alison, L.E. and C.D. Moodle (1965). Carbonate. In: C.A. Black (ed.) "Methods of Soil analysis". Amer. Soc. Agron. Inc., Madison, Washington, USA. pp: 1379-1396.

Ankerman, D. and R. Large (1974). Soil and Plant analysis. A\&L Agric. Lab. Inc. New York, USA, pp: 42-44.

Bouyoucos, H. H. (1954). A recalibration of the hydrometer for making mechanical analysis of soils. Agron. J., 43: 343-348.

Castro, B.F; Locascio, S.J; Olson, S.M. (1988). Tomato response to foliar nutrient and biostimulant applications. Proceedings of the Florida State Horticultural Society. 101, 350 - 353.

Central Agency for Public Mobilization and Statistics, CAMPAS (1996). Statistical Year book, p. 96 .

Chapman, H.D. and Pratt, P.F.(1978). Methods of Analysis for Soils, Plant and Water. 50,Univ. Calif., Dept. Agric. Sci., Priced Publication, 4034, USA.

Chen, Y. and T. Aviad. (1990). Effects of humic substances on plant growth. p.161-186 In P. MacCarthy, C.E. Clapp, R.L. Malcolm, and P.R. Bloom (eds.). Humic substances in soil and crop sciences: selected readings. Am Soc. of Agronomy and Soil Sci. Soc. of Am, Madison, WI.

Chen, Y., Magen, H. and Clapp, C.E. (2001). Plant growth stimulation by humic substances and their complexes with iron. Proceedings No.470, International Fertilizer Society, York, UK. 1-14. 
Chiu, T.F. (1990). Functions and toxicities of micronutrients. In: Proceedings of Symposium on Fruit Tree Nutrition and Orchard Soil Management, L.R. Chang, (Ed.). Special publication No. 20 of Taichung District Agricultural Improvement Station. Changhua, Taiwan ROC. pp: 3543.

David, P.P. (1991). Effects of applied humic acids on yield, growth, nutrient accumulation/ content in selected vegetable crops and soil interactions that reduce their effectiveness. Dissertation Abstracts International B, Sciences and Engineering. 1991; 52(3): 1136-1137.

Delfine, S., R. Tognetti, E. Desiderio and A. Alvino (2005) Effect of foliar application of $\mathrm{N}$ and humic acids on growth and yield of durum wheat. Agron. Sustainable Dev., 25: 183-191.

Dorneanu, A. Dumitru, M. Emilia Dorneanu, C. Preda, Iulia Anton and Ioana Oprică.(2008). Fertilization with liquid humic fertilizers, procedure of high efficiency in improving plant nutrition along the growing season. Proc. 17th Intern. Symp. Of CIEC, 24-27 Nov. Micronutrient Project, Cairo-Egypt, pp. 259-264.

El-Desuki, M. (2004). Response of onion plants to humic acid and mineral fertilizers application. Annals of Agric. Sci, Moshtohor, Vol. 42(4): 1955-1964.

El-Fouly, M.M. (1982). Flower and pod drop. In. Faba bean Improvement.pp.177-184, Proc.Faba bean Conf. (Eds. Hawtin G. \& Webb C.), Publ. Martinus Nijhoff, The Hague, Netherlands.

El-Fouly, M.M; Fawzi, A.F.A.; Firgani, A.H. and El-Baz, F.K. (1984). Micronutrients status of crops in selected areas in Egypt. Commun. Soil Sci. Plant Anal. 15, 1175.

Guvenc,I;Dursun, A;Turan,M;Tuzel,Y;Burrage,SW; Bailey,BJ;Gul,A;Smith,AR;Tuncay,O (1999). Effects of different foliar fertilizers on growth, yield and nutrient content of lettuce and crisp lettuce. Acta-Horticulturae. No. 491, 247-252.

Hafiz, S.I. and El-Kholy, M.A. (2001). Response of two lupine cultivars to phosphorus fertilization and foliar application of potassium and magnesium. Egyptian Journal of Agronomy. 22, 85-105.

Hu Shuixiu and Wang Ruizhen. (2001) A study on the effect of KOMIX, humic acid-containing organic fertilizer, on spring soybean. Acta Agriculturae Universitatis Jiangxiensis, 23(4) 463-466.

Isaac, R.A. and W.C. Johnson (1984). Methodology for the Analysis of Soil, Plant, Feed, Water and Fertilizer amples.California fertilizer Association (CFA). Organic matter determination in soils, pp. 32-33.

Jackson, M.L. (1973). Soil Chemical Analysis. Prentice-Hall of India Private Limited, New Delhi, India. pp: 82-86.

Lindsay, W. L. and W. A. Norvell (1978). Development of DTPA soil test for zinc, iron, manganese and copper. Soil Sci. Soc. Am. J., 42: 421-428.

Mani Sangeetha, Palani Singaram, and Ramar Uma Devi. (2006). Effect of lignite humic acid and fertilizers on the yield of onion and nutrient availability. $18^{\text {th }}$ World Congress of Soil Science. July 9-15, 2006 Philadelphia, Pennsylvania, USA. 
Olsen, S.R., C.V. Cole, F.S. Watanabe and L.A. Dean (1954). Estimation of available phosphorus in soil by extraction by sodium bicarbonate. US Dept. Agric. Circ., 939: 1-19.

Ramasamy Natesan, S. Kandasamy, S. Thiyageshwari, and P. Murugesa Boopathy. (2006). Influence of lignite humic acid on the micronutrient availability and yield of black gram in an alfisol. $18^{\text {th }}$ World Congress of Soil Science. July 9-15, 2006 - Philadelphia, Pennsylvania, USA.

Saad, A.O. M.; El-Kholy, M.A. (2001). Response of some faba bean cultivars to phosphorus and magnesium fertilization. Egyptian Journal of Agronomy. 22, 19-38.

Sillanpãã, M. (1982). Micronutrients and the nutrient status of soils: A global study. FAO Roma, Soils Bull 48. 444.

Snedecor, G.W. and Cochran, W.G. (1980). In "Statistical Methods" $7^{\text {th }}$ Ed., lowa State Univ. Press, Ames,U.S.A.

Tang, C.A.D. Robson, M. J. Dilworth and J. Kuo. (1992). Microscopic evidence on how iron deficiency limits nodule initiation in Lupinus angustifolius L. New Phytol. 121: 457-467.

Waller, R.A. and D.B. Duncan (1969). A bays role for the symmetric multiple comparison problem. Amer. Stat. Assoc. J., 91: 1485-1503.

Wittwer, S.H. and Bukovac, M.J. (1969). The uptake of nutrients through leaf surface. In Handbuch der Pflanzenernahrung und Dungung, Ed. Hans Linser, 235. Springer- Verlag, Wien, New York.

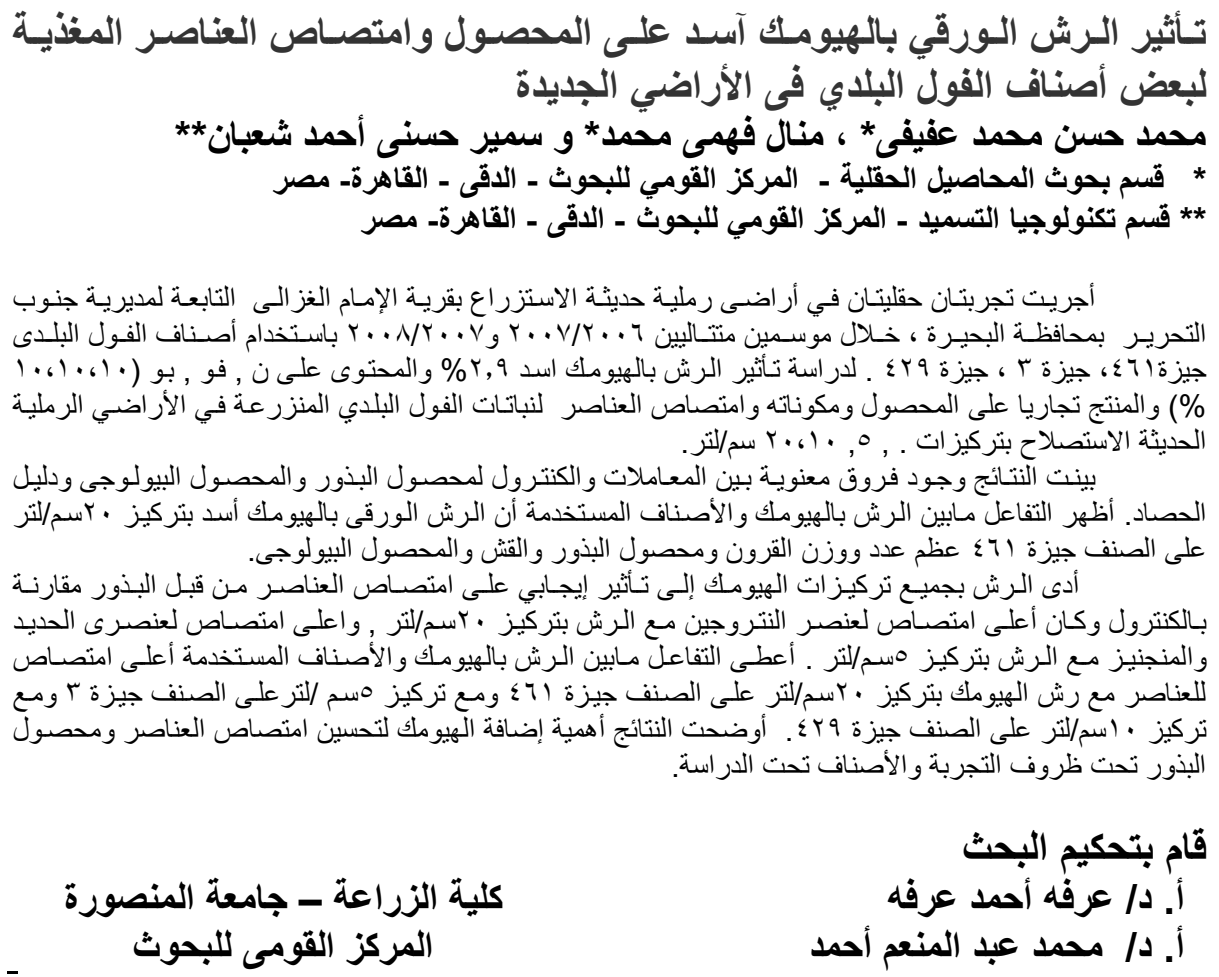

